\title{
Aortic Reconstruction with Cryopreserved Human Allograft in a Hemodialysis Patient with Abdominal Aortic Aneurysm after Surgical Treatment of Liver Abscess
}

\author{
Ivan Kopolovets ${ }^{\mathrm{a}, c}$, Peter Berek ${ }^{\mathrm{a}}$, Vladimir Sihotsky ${ }^{\mathrm{a}}$, Jan Rosocha ${ }^{\mathrm{b}}$ \\ a Department of Vascular Surgery, Eastern Slovak Institute of Cardiovascular Diseases, Faculty of Medicine, P. J. Safarik \\ University, Kosice, Slovak Republic \\ ${ }^{b}$ Tissue Bank, Faculty of Medicine, P. J. Safarik University, Kosice, Slovak Republic \\ 'Uzhhorod National University, Research and Development Department, Uzhhorod, Ukraine
}

ARTICLE INFO

Article history:

Submitted: 27. 5. 2020

Revised: 15. 9. 2020

Accepted: 15. 9. 2020

Available online: 22. 10. 2020

Klúčové slová:

Infekcia

Kryoprezervácia

Vaskulárna alotransplantácia

Xenograft

\section{SÚHRN}

Infekcia v cievnej chirurgii je jedným z hlavných klinických problémov a pacienti s komorbiditami majú vyššie riziko infekčných komplikácií bez ohladu na prístup k liečbe. Jednou skupinou su pacienti, ktorí majú graftinfekciu, kde radikálnou možnostou liečby je odstránenie infikovaného materiálu s následnou rekonštrukciou in situ. Druhou skupinou sú pacienti so známkami infekcie, ktoré si vyžadujú primárnu včasnú aortálnu/arteriálnu rekonštrukciu bez možnosti odkladu operácie. $V$ tejto práci prezentujeme klinický prípad efektívnej chirurgickej liečby aneuryzmy brušnej aorty u polymorbídnej 78-ročnej pacientky s chronickou renálnou insuficienciou. Počas CT vyšetrenia u pacientky zistený absces v lavom laloku pečene a aneuryzma brušnej aorty vel'kosti $10 \times 7 \mathrm{~cm}$ bez známok ruptúry. Na I. chirurgickej klinike vykonali drenáž abscesu pečene. Na 14. pooperačný deň bola pacientka odoslaná na konzultáciu k cievnemu chirurgovi pre bolesti brucha s irradiaciou do chrbtice. Realizovaná CT angiografia, podl'a ktorej je prítomná progresia aneuryzmy brušnej aorty $(10 \mathrm{~cm} \times 7,5 \mathrm{~cm})$ bez zjavnej extravazácie. V oblasti pečene významná regresia velkosti abscesu a sformovaný seróm / absces na ventrálnej ploche lavého laloku pečene. Vzhl'adom na nasledujúce faktory: progresia velkosti aneuryzmy brušnej aorty s rizikom ruptúry, 14. deň po evakuácii abscesu pečene, potvrdený seróm / absces na ventrálnej ploche lavého laloku pečene, klinické prejavy bakteriálnej infekcie (CRP - $78 \mathrm{mg} / \mathrm{l})$, chronická renálna insuficiencia 5 št., rozhodli sme sa vykonat resekciu aneuryzmy aorty s následnou rekonštrukciou s pomocou kryoprezervovaného allograftu. Pooperačné obdobie bolo bez komplikácií, pacientka prepustená na 15. pooperačný deň do ambulantnej starostlivosti.

Záver: Kryoprezervovaný l'udský allograft môže byt' metódou liečby nie len aortálnej graft infekcie, ale aj primárnej rekonštrukcie aorty u pacientov s vysokým rizikom infekcie graftu v pooperačnom období.

(c) 2020, ČK

\section{ABSTRACT}

Background: Infection remains one of the major challenges facing vascular surgery, while patients with comorbidities have an increased risk of infectious complications irrespective of treatment approach. One of the challenges is abdominal aortic graft infection, when the radical treatment option is the removal of the infected material followed by in situ reconstruction, while the other one are patients with infection signs who require primary aortic reconstruction without postponing surgery.

Case presentation: We present a case of effective surgical treatment of abdominal aortic aneurysm in a polymorbid 78-year-old woman with chronic kidney failure. Computer tomography revealed an abscess in the left hepatic lobe and a $10 \times 7 \mathrm{~cm}$ abdominal aortic aneurysm with no evidence of perforation. The liver abscess was drained by surgeons. 14 days after the surgery the patient was still complaining about abdominal pain radiating to lumbar region, so it was referred to a vascular surgeon. CT angiography revealed progression of abdominal aortic aneurysm $(10 \mathrm{~cm} \times 7.5 \mathrm{~cm})$ with no apparent extravasation. Furthermore, significant regression of liver abscess size and a formed collection (seroma) or an abscess pocket on the ventral surface of the left liver lobe were found. Considering the following factors: progression of abdominal aortic aneurysm size with perforation risk, the 14th day after evacuating left lobe liver abscess, confirmed seroma or abscess pocket on the ventral surface of the left liver lobe, clinical manifestations of bacterial infection (CRP - $78 \mathrm{mg} / \mathrm{l})$, stage 5 chronic kidney failure, it was decided that an aortic reconstruction was to be performed with cryopreserved human allograft. The postoperative period was uneventful, and the patient with no signs of early postoperative complications was discharged on the 15th day.

Conclusion: The cryopreserved human allograft is the treatment of choice for both aortic graft infection and primary aortic reconstruction in patients at high risk of graft infection after surgery.
Keywords:

Cryopreservation

Infection

Vascular allotransplantation

Xenograft

Address: Peter Berek, MD, PhD, Department of Vascular Surgery, Eastern Slovak Institute of Cardiovascular Diseases, Ondavska 8, 04001 Kosice, Slovak Republic, e-mail: berekp67@gmail.com

DOI: 10.33678/cor.2020.084 


\section{Introduction}

Abdominal aortic graft infection occurs in approximately $1-3 \%$ of elective surgeries. ${ }^{1}$ High-risk patients (those with mycotic aortic aneurysm, enteral fistulas, history of abdominal abscesses, etc.) who can develop infectious complications in the postoperative period constitute a separate group. ${ }^{2}$ According to literature, the best treatment option in abdominal aortic graft infection is the removal of the infected graft material followed by in situ reconstruction with allografts, xenografts, or silver-coated Dacron grafts. ${ }^{3}$ These treatment methods are recommended for patients who underwent aortic interventions in proven infection of the prosthetic aortic graft or stent graft. However, there are only few publications on the selection of strategy for primary aortic reconstruction in patients with high risk of graft infections. We hereby report a clinical case of surgical treatment of a polymorbid female patient with abdominal aortic aneurysm (AAA) and liver abscess in the left lobe.

\section{Case report}

A 78-year-old woman with stage 5 chronic kidney failure receiving long-term dialysis (the radiocephalic arteriovenous fistula in the left forearm since 2013) was admitted with epigastric abdominal pain and fever. Laboratory testing was done urgently and revealed increased pro-inflammatory markers: CRP $-180 \mathrm{mg} / \mathrm{l}$, leukocytes $-14.2 \times$ $10 \%$. Computer tomography (CT) revealed a liver abscess in the left lobe and AAA $(10 \times 7 \mathrm{~cm})$ with no evidence of perforation (Fig. 1).

The patient was admitted to a surgical department where the evacuation of left lobe abscess was performed.

The postoperative period was uneventful, and the patient was discharged from the department ten days after surgery. After other 5 days, this patient was referred to a vascular surgeon because of abdominal pain radiating to lumbar region. Abdominal ultrasound revealed a 10 $\mathrm{cm} \times 8 \mathrm{~cm}$ sub-renal aneurysm with a posterolateral saccular bend to the left, where there was found a massive thrombus with partial blood flow near the aortic wall. As the exclusion of covered perforation of AAA was impossible, control CT angiography was recommended.

CT angiography revealed significant regression of liver abscess size. Between the ventral surface of the left liver lobe and the anterior abdominal wall in the epigastric region, a formed collection was found. There was AAA progression $(10 \mathrm{~cm} \times 7.5 \mathrm{~cm})$; however, with no apparent extravasation (Fig. 2).

The patient with AAA progression and perforation risk was admitted to the Department of Vascular Surgery.

Preoperative examination revealed the following parameters: CRP - $78 \mathrm{mg} / \mathrm{l}$, leukocytes - $12.3 \times 10^{\circ} / \mathrm{L}$.

Considering overall factors, namely progression of AAA size with high risk of perforation, the 14th day after the evacuation of liver abscess in the left lobe, confirmed seroma or abscess pocket on the ventral surface of the left liver lobe, clinical manifestations of bacterial infection (CRP - $78 \mathrm{mg} / \mathrm{l})$, stage 5 chronic kidney failure, aortic reconstruction was decided to be performed with the

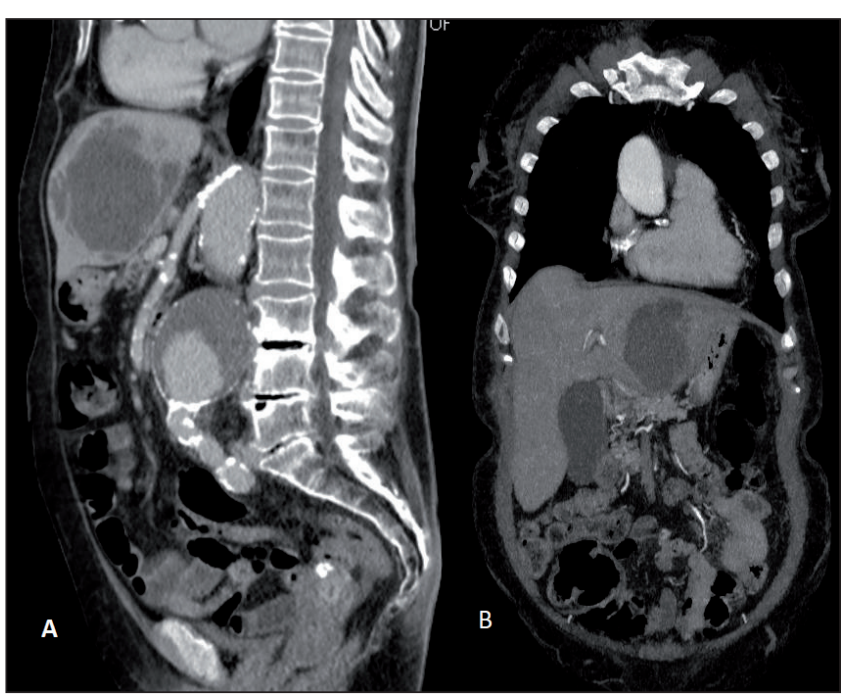

Fig. 1 - (A) Left lobe liver abscess and abdominal aortic aneurysm (sagittal plane); (B) left lobe liver abscess (coronal plane).

cryopreserved human allograft. This surgical solution was approved by the ethics committee of the Eastern Slovak Institute of Cardiovascular Diseases and written informed consent was obtained from the patient.

\section{Operative details}

Midline laparotomy was used to gain surgical access. In the upper midline incision above the aponeurosis, there was found an abscess that was drained and washed out thoroughly with antiseptics.

The next stage included the preparation of the retroperitoneal space followed by AAA mobilization. The

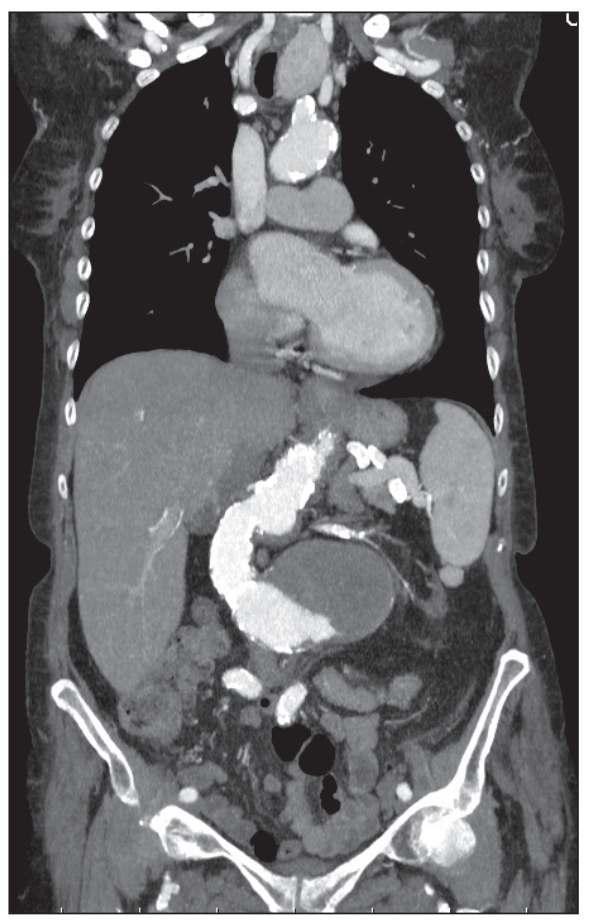

Fig. 2 - Abdominal aortic aneurysm (coronal plane). 
cryopreserved human allograft was prepared according to the standard protocol. The frozen cryopreserved human allograft taken from the biobank one hour before surgery was thawed in a $37{ }^{\circ} \mathrm{C}$ water bath. Then, it was thoroughly washed three times with saline solution, prepared for reconstruction and placed into solution.

After the aneurysm was opened and the lumbar arteries were ligated, the proximal end-to-end anastomosis between the aorta and the allograft was done at the level of the renal arteries; the distal anastomosis was performed above the aortic bifurcation (Fig. 3).

In the postoperative period, antibiotic therapy was prescribed according to antibiotic susceptibility that was detected during the evacuation of liver abscess (ciprofloxacin $2 \times 200 \mathrm{mg}$, ampicillin/sulbactam $3 \times 1.5 \mathrm{~g}$ ). Bacterial culture collected from the site of the abscess of the anterior abdominal wall revealed Enterococcus faecium; therefore, on the third postoperative day, antibiotic therapy was altered by susceptibility (vancomycin $3 \times 500 \mathrm{mg}$ ).

The postoperative period was uneventful, and the patient with no signs of early postoperative complications was discharged from the clinic on the 15th day with instructions to take ciprofloxacin - 1×500 mg for 20 days and prednisone $-1 \times 5 \mathrm{mg}$ for 1 month.

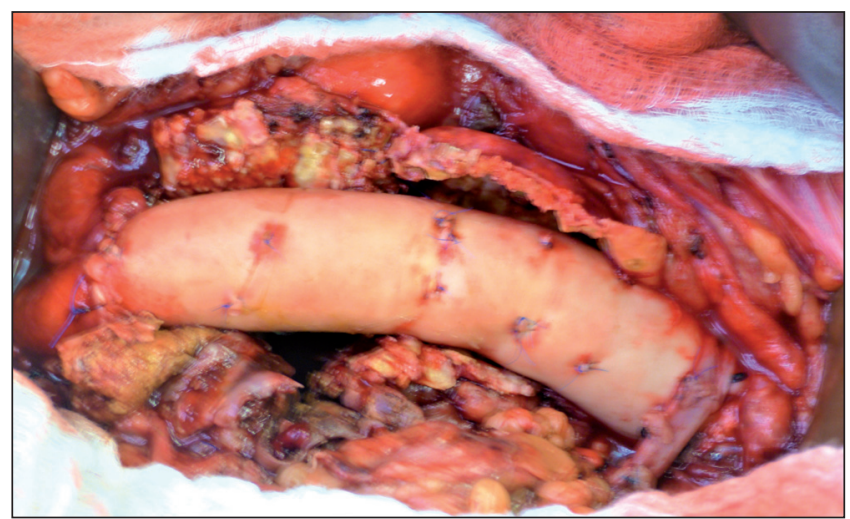

Fig. 3 - Resection of abdominal aortic aneurysm followed by reconstruction with the cryopreserved human allograft (intraoperative photograph).

\section{Discussion}

Treatment of aortic graft infection is an important problem and quite a disputable one. To find the best solution is not an easy task; moreover, each variant of reconstruction known today (conservative treatment - antibiotic therapy, antibiotic-soaked polyester prosthetic graft, xenograft, allograft, extraanatomical reconstruction) has its advantages and disadvantages. ${ }^{4,5}$ The choice of strategy for primary aortic reconstruction in high risk of graft infection is a separate issue. ${ }^{3}$

In our case, the main risk factor, in addition to kidney failure, was bacterial infection caused by the abscess of the anterior abdominal wall that formed after surgical treatment of liver abscess in the left lobe (on the 14th day after the abscess was drained). Probably the best treatment option for this patient would have been draining the abscess of the anterior abdominal wall and adequate antibiotic therapy until clinical and laboratory signs of bacteremia disappeared; and only then, over the longterm period, the AAA resection. However, the presence of abdominal pain radiating to the lumbar region, the progression of AAA size according to $C T$ findings gave reasons to make the diagnosis of symptomatic AAA which is an indication for surgery within 72 hours.

Opting among different surgical tactics, we preferred aortic reconstruction with the cryopreserved human allograft. We made this decision based on the experience of using the cryopreserved human allograft in our clinic while treating aortic/arterial infection and achieving good postoperative outcomes. ${ }^{4}$

In the process of using allografts, a number of changes occurred, namely fresh human allografts have been replaced with cryopreserved human allografts. These changes were associated with higher incidence of postoperative complications such as bleeding, dilatation and anastomotic pseudoaneurysm when using fresh allografts as compared to cryopreserved human allografts. ${ }^{5}$ The portion of the artery or the aorta to which the allograft is sutured affects the development of pseudoaneurysm as well. Therefore, anastomosis is recommended to be sutured in the area of the healthy arterial wall. ${ }^{7}$ In our case, the risk of developing pseudoaneurysm was low, as it was primary aortic reconstruction where the aortic wall was not infected.

The methods of cryopreservation have allowed achieving highly effective sterilization of allografts. In the USA (CryoLife, Inc., Kennesaw, GA), for example, allografts are stored at temperature of $-180{ }^{\circ} \mathrm{C}$ to $-196{ }^{\circ} \mathrm{C}$ being previously exposed to vancomycin, lincomycin, and dimethyl sulfoxide. ${ }^{6,7}$ It is interesting that cryopreservation of the aortic transplant $\left(-190{ }^{\circ} \mathrm{C}\right.$ to $\left.-100{ }^{\circ} \mathrm{C}\right)$ provides an excellent resistance to $S$. aureus. ${ }^{6}$ Moreover, cryopreservation methods allowed reducing the immune response in the postoperative period. Although the immune response is also a disputable issue, and the advisability of long-term use of immunosuppressive agents is still under discussion. ${ }^{8}$ In the postoperative period, we prescribed prednisone at a dose of $5 \mathrm{mg}$ once a day for a month.

There are some publications suggesting that allografts are prone to thrombosis due to foreign body response. ${ }^{5}$ In our experience, when using cryopreserved human allografts, we have never observed thrombosis, especially in aortic reconstruction.

In one of the largest studies on the use of allografts, MP Harlander-Locke et al. concluded that cryopreserved human allografts should be considered a first-line treatment of aortic infections as it allows achieving good, both early and long-term, outcomes in patients with aortic graft infection and those at high risk of postoperative infection. $^{9}$

The use of xenografts is an alternative to using cryopreserved human allografts. The publications on good results of using xenografts in aortic graft infection have recently appeared. ${ }^{2,10}$ The ability to obtain the graft size needed for reconstruction is one of the advantages of using a xenomaterial for grafting. ${ }^{1}$

The next possibility is the use of the antibiotic-soaked polyester prosthetic graft; however, according to literature, re-infection occurs in approximately $10 \%$ of cases. $^{3}$ 
The duration of antibiotic therapy in radical surgeries for aortic graft infection (removal) is also under discussion. Some authors recommend antibiotic therapy within 4-6 weeks, while others offer long-term suppressive antibiotic therapy. ${ }^{4,7}$

\section{Conclusions}

Infection remains one of the major clinical challenges facing vascular surgery, and patients with comorbidities increase the risk of developing infectious complications irrespective of treatment approach. The cryopreserved human allograft or the xenograft is the treatment of choice for aortic graft infection, as well as primary aortic reconstruction in patients with high risk of developing graft infection in the postoperative period.

\section{Conflict of interest}

The authors declare that they have no competing interests. All authors read and approved the final manuscript.

\section{Funding}

No institution provided financial support for the conduct of the research and/or preparation of the article

\section{Authors' contributions}

IK participated in drafting the article and designed the paper, PB performed the surgery and provided the necessary photos, VS revised the manuscript and was the consultant of the case report, JR revised the manuscript

\section{References}

1. Kreibich M, Siepe M, Morlock J, et al. Surgical Treatment of Native and Prosthetic Aortic Infection With Xenopericardial Tube Grafts. Ann Thorac Surg 2018;106:498-504.

2. Anibueze C, Sankaran V, Sadat U, et al. Neoaortic Xenoprosthetic Grafts for Treatment of Mycotic Aneurysms and Infected Aortic Grafts. Ann Vasc Surg 2017;44:419.e1-419. e12.

3. Bisdas T, Wilhelmi M, Haverich A, Teebken OE. Cryopreserved arterial homografts vs silver-coated Dacron grafts for abdominal aortic infections with intraoperative evidence of microorganisms. J Vasc Surg 2011;53:1274-1281.e4.

4. Sihotsky V, Berek P, Mathews AJ, et al. Infected thoracic stentgraft and prosthetic graft with replacement by human aortic allograft. Cor Vasa 2019;61:e519-e523.

5. Ben Ahmed S, Louvancourt A, Daniel G, et al. Cryopreserved arterial allografts for in situ reconstruction of abdominal aortic native or secondary graft infection. J Vasc Surg 2018;67:468477.

6. Janko MR, Bose S, Lawrence PF. Current status of treatment for aortic graft infection: When should cryopreserved allografts be used? Semin Vasc Surg 2019;32:81-87.

7. Mestres CA, Quintana E, Kopjar T, et al. Twenty-year experience with cryopreserved arterial allografts for vascular infections. Eur J Cardiothorac Surg 2019;55:358-365.

8. Fazekas G, Benkö L, Kasza G, et al. Histological and Mechanical Assessment of Decellularized Porcine Biografts, and Its Biological Evaluation following Aortic Implantation during Mid-Term Follow-Up. J Vasc Res 2018;55:287-298.

9. Harlander-Locke MP, Harmon LK, Lawrence PF, et al. The use of cryopreserved aortoiliac allograft for aortic reconstruction in the United States. J Vasc Surg 2014;59:669-674.

10. Czerny $M$, von Allmen $R$, Opfermann $P$, et al. Self-made pericardial tube graft: a new surgical concept for treatment of graft infections after thoracic and abdominal aortic procedures. Ann Thorac Surg 2011;92:1657-1662.

\section{Acknowledgements}

Not applicable. 